\title{
Competencies in Physical Education Teaching: An Investigation of Teachers' Perceptions in the Southern Governorates of Jordan
}

\author{
Adnan M. Al-Tawel \\ Curriculum \& Instruction Department, Al-Hussein Bin Talal University, Ma'an, Jordan \\ E-mail: banarama64@yahoo.com
}

Ibraheem A. AlJa'afreh

Curriculum \& Instruction Department, Al-Hussein Bin Talal University, Ma'an, Jordan

Received: Jan. 23, 2017 Accepted: April 4, 2017 Published: May 1, 2017

doi:10.5296/jse.v7i2.11262 URL: https://doi.org/10.5296/jse.v7i2.11262

\begin{abstract}
The purpose of this study was twofold: (1) to investigate physical education teachers' perceptions of their teaching competencies (2) to examine potential differences in physical education teachers' perceptions of their teaching competencies based on their gender and academic qualification. Descriptive approach was selected to guide the study. The study consisted of 127 physical education teachers from schools in four Governorates at the Southern of Jordan: Tafila, Maan, Aqaba, and Karak. A questionnaire instrument was used to collect data from the participants. The questionnaire instrument consisted of four scales: planning competencies, implementation competencies, personal and social competencies, and motivational competencies. The results showed that the participants' perceptions of the levels of their educational competencies varied between low and high. The participants believed that the level of their planning competencies was low. While they believed that the level of their implementation competencies was high. The participants believed that the level of their personal/social and motivational competencies was moderate. The findings showed that there were significant differences in the physical education teachers' perceptions of the levels of their educational competencies based on their gender and academic qualifications. Based on the findings, recommendations were presented.
\end{abstract}

Keywords: Jordan, Physical education, Teachers, Competencies, Perceptions, Teaching. 


\section{Introduction}

Qualified teachers who can deliver high quality instruction are significant for students' success and motivation in schools (Seferoglu, 2005; Siegle, Rubenstein, \& Mitchell, 2014). The teacher is the cornerstone of the educational process. Teachers are responsible for providing students with knowledge, skills and experience within and outside the classroom. Therefore, preparing the teachers to meet the demands and requirements of the teaching profession is significant in all educational systems. Teachers should possess high levels of teaching competencies. Competencies can be defined as "the positive combination of knowledge, ability and willingness in the availability of the individual to cope successfully and responsibly with changing situations" (Weinert, 2001, p. 27).

Educational competencies consist of three core types: "competencies required for classroom teaching, competencies essential for carrying out professional engagements in school, and competencies needed to be a positive contributor of society" (Bhargava \& Paty, 2010, p. 8). Askar (2008) summarized the needed educational competencies for teachers in schools; these competencies were grouped in five dimensions:

- General competencies that include the abilities for psychological and social adjustment and the abilities for social, economic, and professional development;

- $\quad$ specialized competencies that include sufficient knowledge and skills in the educational material or subjects to be taught;

- teaching related competencies that include recognizing students' differences, knowing educational requirements for each educational stage; possessing the knowledge and skills to solve students' educational problems, possessing the knowledge and skills for guidance and psychological counseling for students; knowing the different teaching methods, possessing the knowledge and skills in using educational and technological tools, and possessing the knowledge and skills needed for evaluating the students' learning.

- social and cultural competencies that include knowing the cultural and the social characteristics of the community and knowing the role of the teachers in developing the society.

- $\quad$ self-development competencies that include possessing the knowledge and skills to use the sources of information which are necessary for professional growth through self-learning

Physical education is one of the pillars of the general educational program. Physical education aims to develop the individuals' psychological, mental and physical health. It develops individual to become an active member of the society (Badeda \& Shabeba, 2012; Abu-Jameh, 2013). The roles of physical education teachers are very important in the schools. The duties of the physical education teachers have multiple facets that include designing and implementing physical and sports activities that contribute in developing and enhancing students' values and ethics; improving their physical abilities, strength, psychological health, motor skills and social attitudes; and maximizing physical activity opportunities for the students (Bailey, 2006; Castelli \& Beighle, 2007; Abu-Jameh, 2013). 
However, physical education teachers should possess high level of educational competencies in order to be able to successfully deliver instruction, manage classroom, and contribute in students' developments. Kyrgiridis et al, (2014) reported that the instrument that assess physical education teachers' competencies should consist of six domains: applications of the content of physical education, lesson implementation, learning environments, teaching strategies, student and teacher assessment, and use of technology. Chen et al (2014) argued that to deliver quality physical education, teachers should master four competencies including task design, task presentation, class management, and instructional guidance.

Furthermore, physical education teachers should possess specific basic educational competencies that include: planning competencies, implementation competencies, personal and social competencies, and motivational competencies (Stojanović \& Zdravković , 2012; Abu-Jameh, 2013; Hand, 2014; Tul, Leskosek, Jurak, \& Kovac, 2015). Teachers’ planning competencies include: determining the needs of students in accordance with their demographic characteristics; choosing and classifying the appropriate educational goals and objectives; identifying the appropriate teaching procedure, methods, and activities; developing daily, weekly and annual educational plans; and selecting the appropriate educational sport tools (Abdul-Samie \& Hawala, 2005; Tul, Leskosek, Jurak, \& Kovac, 2015; Chen et al., 2016). Teachers' implementation competencies include: allowing the students to perform individual and group educational activities, considering individual differences among students in light of their needs and capabilities, demonstrate sport skills in front of students, facilitate effectiveness communication among students and between students and instructor (Abdul-Samie \& Hawala, 2005, Stojanović \& Zdravković, 2012). Teachers' personal and social competencies include: knowing the characteristics of the local community and the social environment in which the students come from, dealing with different social situations in the work, modifying the behavior of the students, participating in the development of community-based projects implemented by the school with the participation of civil society institutions to serve students and their social environments, encouraging students to participate in social activities, developing students' personalities through social relations, cooperating with the local community, providing students with social skills needed to form successful relationships with others, developing students' sense of worth as a useful members of society, emphasizing on the schools' roles for positively influencing the community (Hilal \& Tawfek, 2007; Stojanović \& Zdravković, 2012). Teachers' motivational competencies include: creating warm and accepting learning environments that promote students' positive attitudes toward teaching and learning, providing students with timely and proper incentives that are expected to motivate students at a particular time, supporting and developing students' readiness to learn, and encouraging entrepreneurship among the students (Ololube, 2005).

Physical teachers' roles are important in the educational process. Physical teachers' educational competencies are significant to facilitate students' learning. There are varieties of the educational and personal competencies needed for effective teaching in physical education field. The purpose of this study was twofold: (1) to investigate physical education teachers' perceptions of their educational competencies (2) to examine potential differences 
in physical education teachers' perceptions of their teaching competencies based on their gender and academic qualification.

\section{Literature Review}

There are several research studies that examined physical education teachers' competencies. The current section presents sample of these studies. First, international research studies were discussed followed by research studies from Arab world. Then, research studies from Jordan were presented.

In Serbia, Stojanović and Zdravković (2012) examined physical education teachers' perceptions of their level of competencies in teaching physical education. In addition, the study investigated the differences in their perceptions based on their gender, teaching level, and work experience. For the purpose of the study, 92 physical education teachers completed a questionnaire. The questionnaire aimed to assess teachers' knowledge and skills in teaching physical education, the way and type of their educational abilities, knowledge of students' characteristics, knowledge and skills in planning, knowledge and skills in educational counseling, knowledge and skills in collaboration with the local community, knowledge of inclusive education, and practical competencies. The results showed that the teachers attributed a high value to their own competencies in all areas of physical education teaching. The teachers had perceived the highest level of their competencies in the areas related to the teaching process. Participants' education and experiences were considered as the main reasons for their level of competencies. In addition, the results showed that there were no significant differences in the perceived competencies according to their gender, teaching level, and experience.

In USA, Hand (2014) examined physical education pre-service physical educators' perceptions of their proficiencies in teaching. In addition, the study examined the factors that influence their evaluation of their level of educational competencies. One hundred and forty nine pre-service physical educators completed two questionnaires. The first questionnaire measured participants' perceived competencies in six areas: scientific knowledge, sport skills and fitness, planning and implementation competencies, instructional delivery and management competencies, impact on student learning, and professionalism. The second questionnaire measured teachers' perceptions of the potential factors that might affect their evaluation of their teaching competencies. The results showed that the participants believed that they possess moderate to high level of physical education teaching competencies. In addition, the results showed that the most common perceived factors that would affect students' teaching efficacy were: teaching experiences, opportunities to receive immediate teaching feedback, and observing competent teachers.

In Slovenia, Tul, Leskosek, Jurak, and Kovac, (2015) examined physical education teachers' perceptions of the importance of professional competencies. Cross-sectional survey design was used in this study, in which 672 physical education teachers completed a questionnaire. The results showed that teachers perceived that the pedagogical content knowledge competencies as the most important competencies for physical education teachers. The other perceived important competencies among the teachers arranged in descending order were 
related to: social science aspects of sport; general pedagogical knowledge; biological and physiological aspects of sport; teaching methods; general didactic knowledge; research, entrepreneurship, organization; communication skill; planning; responsible behavior; and leadership and motivation.

In Turkey, Demir (2015) examined school students' perceptions of the professional personality competencies of their physical education teachers. For the purpose of the study, 1,254 students completed Physical Education Teacher Professional Personality Competence Scale-Students (PET PPCS-Student) questionnaire. The questionnaire consisted of four domains: motivational interaction, professional enthusiasm and dedication, human dignity and justice, and reflective interaction. The results showed that the students perceived that their physical education teachers had high level of professional personality competencies. "Professional enthusiasm and dedication" scale had highest average points while "respect for human dignity and justice" scale had lowest average points.

In Iraq, Abd-Albaqi et al, (2011) examined the competencies of physical education teaching among primary education teachers in Iraq. One hundred and twenty physical education teachers completed a cross sectional questionnaire. The questionnaire measured the extent to which the teachers believed they possess competencies in five teaching aspects: educational objectives, planning, implementation, teaching methods, and evaluation. The results showed that the teachers believed that they possess moderate level of competencies in planning, implementation, teaching methods, and evaluation aspects. However, they perceived that they possess high level of competencies in educational objectives aspect.

In another study in Iraq, Selim and Hassan (2011) investigated physical education teachers' perceptions of the levels of their competencies in teaching physical education in the centers of governorates of: Irbil, Sulaymaniyah and Dohuk. Sixty one physical education teachers completed a cross sectional questionnaire. The questionnaire consisted of seven dimensions: planning competencies, implementation of the lesson plans and the use of teaching methods competencies, classroom management competencies, subject matter knowledge competencies, using of teaching aids competencies, evaluation competencies, and designing and conducting educational activities competencies. The results showed that the physical teachers ascribed a moderate to high value to their own competencies in the areas of physical education teaching. In addition, the results showed that the male teachers outperformed female teachers in some competencies that include: implementation of the lesson plans and the use of teaching methods competencies, subject matter knowledge competencies, and designing and conducting educational activities competencies.

In Oman, Al-Rawahi and Al-Hanai (2013) investigated the level of educational competencies of physical education teachers and the potential differences in physical education teachers' level of these educational competencies based on their gender, experience, and educational region. Descriptive statistic approach was used in the study, in which 310 teachers, who were randomly selected, completed a questionnaire instrument. The instrument consisted of five scales: planning competencies, implementation competencies, class management competencies, evaluation competencies, and professional and scientific competencies. The 
results showed that the possession level of educational competencies ranged from low to high. In addition, the results showed that there were no significant differences in teachers' perceived levels of their educational competencies based on their gender and educational region. However, there were significant differences in teachers' perceived levels of their educational competencies based on their experiences. The physical education teachers who had long teaching experience reported a higher level of educational competencies compared to teachers with short teaching experience.

In Jordan, Abu-Nimra (2003) examined the perceptions of teachers and schools principals of the levels of educational competencies of physical education teachers in elementary education stage. In addition, the study examined the differences in their perceptions of the level of physical education teachers' competencies based on their gender, experience, and academic qualification. The study sample consisted of 243 teachers and 62 schools principals who were randomly selected from The United Nations Relief and Works Agency (UNRWA) schools. The used instrument was a questionnaire that consisted of three dimensions: planning for teaching competencies, the implementation of teaching competencies, and evaluation competencies. The results showed that the teachers believed that the level of educational competencies in physical education teaching was high. While the schools principals believed that the level of educational competencies of physical education teachers was moderate. In addition, the results showed that there were no statistically significant differences in the perceptions of teachers and schools principals of the level of educational competencies of physical education teachers based on gender, experience, and academic qualification.

In Jordan, Hadidi and Dahmach (2013) examined female physical education teachers' perceptions of training needs and the differences in their perceptions of the training needs based on their experience and the type of the school: private or public. Three hundred physical education teachers from the capital governorate (Amman) completed a questionnaire. The questionnaire consisted of seven dimensions: planning and teaching, knowledge, technical skills, professional growth, teaching methods, classroom management and system maintenance, and students' assessment. The results indicated that the teachers' training needs were perceived as moderate. In addition, there were significant differences in the perceived training needs based on experience in favor of teachers who had less than (5) years teaching experience. Furthermore, there were significant differences in the perceived training needs based on the type of the school in favor of the private schools.

The previous research studies showed that the educational competencies of physical education teachers had attracted research attentions in different countries due to the importance of the relationship between teachers' competencies and students' learning. The data regarding educational competencies of physical education teachers were collected from different resources that include the teacher themselves (Stojanović \& Zdravković 2012; Hand, 2014; Tul, Leskosek, Jurak, \& Kovac, 2015; Abd-Albaqi et al, 2011; Selim \& Hassan 2011; Al-Rawahi \& Al-Hanai,2013; Abu-Nimra 2003; Hadidi \& Dahmach, 2013), and their students (Demir (2015);); and their schools principles (Abu-Nimra, 2003). In the previous discussed literature, the research studies used descriptive research design in which the 
participants completed a cross sectional questionnaire. The previous research studies examined physical education teachers' possession of different types of educational related competencies. Mixed results were found regarding the differences in physical education teachers' perceived competencies based on different variables. For instance, Abu-Nimra (2003) and Stojanović and Zdravković (2012) found that that there were no significant differences in teachers' perceived competencies according to their gender, teaching level, experience, and academic qualification. On the other side, Selim and Hassan (2011) found that that there were significant differences in teachers' perceived competencies according to their gender, Al-Rawahi and Al-Hanai (2013); Hadidi and Dahmach (2013); and Hand (2014) found that that there were significant differences in teachers' perceived competencies according to their experience. Considering the varieties in educational competencies of physical education teachers, the mixed results regarding the educational competencies of physical education teachers and the factors that influence these competencies, and the lack of research studies that examined educational competencies of physical education teachers in the Southern Governorates of Jordan, the current study aimed to investigate physical education teachers' perceptions of their teaching competencies and the factors that might influence their teaching competencies in the Southern Governorates of Jordan.

\section{Purpose of the Study}

Based on the nature of the jobs of the authors of this study in physical education domain at Southern of Jordan, the authors noticed that there were variations in physical education teachers' competencies and there were several factors that might influence their educational competencies. Therefore, to understand the level of physical education teachers' competencies, a group of physical education teachers, at schools in the Governorates at Southern of Jordan, were selected to participate in this study to shed light on the actual status of their educational competencies and the factors that might influence the levels of their educational competencies. The purpose of this study was twofold: (1) to investigate physical education teachers' perceptions of their teaching competencies (2) to examine potential differences in physical education teachers' perceptions of their teaching competencies based on their gender and academic level. The research questions guiding this study were:

1. What are the perceptions of the physical education teachers, in the Southern Governorates of Jordan, of the levels of their educational competencies?

2. Are there any statistically significant differences $(\alpha<0.05)$ in physical education teachers perceived levels of educational competencies based on their gender and academic qualification?

\subsection{Importance of the Study}

This study shed light on the actual status of the physical education teachers' educational planning, implementation, social and personal, and motivational competencies. In addition, the study shed light on the factors that might influence the levels of physical education teachers' educational competencies. The findings of this study would help different stakeholders in the physical education domain to develop and enhance physical education 
teachers' educational competencies through providing them with the appropriate training, and support programs and activities. The findings of the current study contributed to the body of knowledge in relation to physical education teachers' educational competencies in Arab world in general and in Jordan in particular. The current study was among a few studies that focused on physical education teachers' educational competencies in Arab world in general and in Jordan in particular.

\section{Methodology and Research Design}

Descriptive methods research approach was used in the current study. Data were collected using a questionnaire instrument. The questionnaire instrument consisted of four dimensions: planning competencies, implementation competencies, personal and social competencies, and motivational competencies.

\subsection{Study sample}

The study sample consisted of 127 physical education teachers in the schools of Southern Governorates of Jordan: Tafila, Maan, Aqaba, and Karak. The study sample was selected purposively according to their willingness to participate in the study. The participating female teachers represented a little more than half of the participants $(55.90 \% ; n=71)$. Most of the participants $(85.04 \% ; n=108)$ hold bachelor degree or university certificate or diploma below the bachelor level. Only $14.96 \%(n=19)$ hold graduate degree. (See Table 1)

Table 1. Descriptive Summary of Participants’ Demographic Data

\begin{tabular}{|l|l|l|l|}
\hline & Category & Frequency & Percent \\
\hline Gender & $\begin{array}{l}\text { Male } \\
\text { Female }\end{array}$ & 56 & 44.10 \\
71 & 55.90 \\
\hline $\begin{array}{l}\text { Academic } \\
\text { Qualification }\end{array}$ & $\begin{array}{l}\text { Undergraduate degree or } \\
\text { academic degree below the } \\
\text { bachelor level } \\
\text { Graduate degree }\end{array}$ & 108 & 85.04 \\
\hline
\end{tabular}

\subsection{Data Collection Methods}

The researchers developed a questionnaire instrument to collect data. The items in the data collections instrument were chosen and developed according to different research studies. Some of these research studies include (Stojanović \& Zdravković, 2012; Hand, 2014); Tul, Leskosek, Jurak, \& Kovac, 2015; Selim \& Hassan 2011; Abu-Nimra, 2003); Hadidi \& Dahmach, 2013). The questionnaire consisted of 27, five-point Likert-type, items grouped into four dimensions: planning competencies, implementation competencies, personal and social competencies, and motivational competencies. The entire questionnaire items existed in the discussion section. 


\subsection{Validity and Reliability of the Instruments}

A jury of experts reviewed the questionnaire instrument to ensure its validity. The jury consisted of experts in physical education and educational measurement and evaluation. The jury members were asked to review the language and the content of the items. According to the experts' notes, the researchers reviewed the questionnaire instrument.

\subsection{Variables of the Study}

The dependant variable in the current study was physical education teachers' perceptions of the levels of their teaching competencies. These teaching competencies were categorized in four domains: planning competencies, implementation competencies, personal and social competencies, and motivational competencies. The independent variables in this study were gender and academic level. The academic level has two options (i.e., First, undergraduate degree or academic degree below the bachelor level and second, graduate degree).

\subsection{Data Collection Procedure}

The researchers personally visited some randomly selected schools in the Southern Governorates of Jordan in order to obtain the principals' approval to have the physical education teachers in their schools to participate in the study and to collect data about the number of the physical education teachers in these schools. After acquiring principals' approval and physical education teachers' consent to participate in the study, the researchers, in face-to-face settings, handed out paper-format questionnaires to the physical education teachers in these schools, to explore their perceptions of their teaching competencies.

\subsection{Data Analysis}

In order to answer the research questions, the following levels of the scores on 5-point likert scale were adopted (Table1)

Table 1. The Levels of the Mean Scores on 5-point Likert Scale

\begin{tabular}{|l|l|}
\hline Mean scores & Level \\
\hline Less than 1.5 & Very low \\
\hline Between 1.5 and 2.5 & Low \\
\hline Between 2.5 and 3.5 & Moderate \\
\hline Between 3.5 and 4.5 & High \\
\hline Between 4.5 and 5 & Very high \\
\hline
\end{tabular}

Descriptive statistics that include means and standard deviations were used to illustrate physical education teachers' perceptions of the levels of their teaching competencies. Independent sample t-tests were carried out to examine variations in physical education teachers' perceptions of the levels of their teaching competencies according to their gender and academic levels. Data were analyzed using SPSS software. 


\section{Results}

5.1 First research question: What are the perceptions of the physical education teachers, in the Southern Governorates of Jordan, of the levels of their educational competencies?

To answer the first research question, means and standard deviations for the each items of the questionnaire instrument were calculated. The teaching competencies were grouped into four dimensions: planning competencies, implementation competencies, personal and social competencies, and motivational competencies (Tables 2, 3, 4, 5).

\subsubsection{Planning competencies}

The results showed that the participants perceived level of their planning competencies was low (Table 2)

Table 2. Descriptive statistics of participants' responses to perceived level of planning competencies scale. $(N=127)$

\begin{tabular}{|l|l|l|l|l|}
\hline & Planning competencies & $\mathrm{M}$ & $\mathrm{SD}$ & Level \\
\hline 1 & $\begin{array}{l}\text { I can employ the educational activities proposed by } \\
\text { the Jordanian Ministry of Education. }\end{array}$ & 2.06 & 1.16 & Low \\
\hline 2 & $\begin{array}{l}\text { I have the ability to choose appropriate educational } \\
\text { objectives and goals for each educational stage. }\end{array}$ & 2.10 & 1.15 & Low \\
\hline 3 & I can clearly set the educational objectives and goals. & 2.32 & 1.16 & Low \\
\hline 4 & $\begin{array}{l}\text { I can identify appropriate educational procedures to } \\
\text { achieve the educational objectives and goals. }\end{array}$ & 2.35 & 1.31 & Low \\
\hline 5 & $\begin{array}{l}\text { I can select the appropriate educational activities } \\
\text { depending on the available facilities in the school }\end{array}$ & 2.71 & 1.35 & Moderate \\
\hline 6 & $\begin{array}{l}\text { I can prepare quarterly and annual plans that organize } \\
\text { the content of the course. }\end{array}$ & 2.73 & 1.50 & Moderate \\
\hline 7 & $\begin{array}{l}\text { I can select the proper sports tools to achieve the } \\
\text { educational objectives and goals. }\end{array}$ & 2.78 & 1.39 & Moderate \\
\hline & Overall planning competencies scale & 2.44 & .62 & Low \\
\hline
\end{tabular}

Table 2 shows that the level of overall perceived level of planning competencies among physical education teachers was low $(M=2.44, S D=.62)$. The means of teachers responses to the items of planning competencies scale varied between low $(M=2.06, S D=1.16)$ and moderate $(M=2.78, S D=1.39)$. The teachers responded most favorably to item 7 "I can select the proper sports tools to achieve the educational objectives and goals" $(M=2.78, S D=1.39)$. The teachers responded least favorably to item1" I can employ the educational activities proposed by the Ministry of Education" $(M=2.06, S D=1.16)$. 


\subsubsection{Implementation competencies}

The results showed that the participants perceived level of their implementation competencies was high (Table 3)

Table 3. Descriptive statistics of participants' responses to perceived level of implementation competencies scale. $(N=127)$

\begin{tabular}{|l|l|l|l|l|}
\hline & Implementation competencies & $\mathrm{M}$ & $\mathrm{SD}$ & Level \\
\hline 1 & $\begin{array}{l}\text { I can build on the students' sports skills to teach them } \\
\text { new ones. }\end{array}$ & 3.24 & 1.38 & Moderate \\
\hline 2 & I can clearly explain the educational skills for students. & 3.25 & 1.38 & Moderate \\
\hline 3 & $\begin{array}{l}\text { I can use appropriate educational methods to teach } \\
\text { students. }\end{array}$ & 3.46 & 1.40 & Moderate \\
\hline 4 & \begin{tabular}{l} 
I can demonstrate the sport skills in front of the students. \\
\hline 5
\end{tabular} & 3.61 & 1.27 & High \\
\hline 6 & I can recognize individual differences among students. & 3.64 & 1.45 & High \\
\hline 7 & $\begin{array}{l}\text { I can easily present and discuses different components } \\
\text { of the lesson. }\end{array}$ & 3.90 & 1.10 & High \\
\hline & Overall & 3.53 & .62 & High \\
\hline
\end{tabular}

Table 3 shows that the level of overall perceived implementation competencies among physical education teachers was high $(M=3.53, S D=.62)$. The means of teachers responses to the items of implementation competencies scale varied between moderate $(M=3.24$, $S D=1.38)$ and high $(M=3.90, S D=1.10)$. The teachers responded most favorably to item7 "I can easily present and discuses different components of the lesson" $(M=3.90, S D=1.10)$. The teachers responded least favorably to item1 "I can build on the students' sports skills to teach them new ones" $(M=3.24, S D=1.38)$.

\subsubsection{Personal and social competencies}

The results showed that the participants perceived level of their personal and social competencies was moderate (Table 4) 


\section{Macrothink}

Table 4. Descriptive statistics of participants' responses to perceived level of personal and social competencies scale. $(N=127)$

\begin{tabular}{|c|c|c|c|c|}
\hline & Personal and social competencies & $\mathbf{M}$ & SD & Level \\
\hline 1 & $\begin{array}{l}\text { I can use the appropriate reinforcement methods for } \\
\text { students' behavior. }\end{array}$ & 2.45 & 1.64 & Low \\
\hline 2 & $\begin{array}{l}\text { I do not find difficulties in managing classroom during the } \\
\text { educational process. }\end{array}$ & 2.51 & 1.74 & Moderate \\
\hline 3 & $\begin{array}{l}\text { I do care of my physical appearance and my personal } \\
\text { health and hygiene. }\end{array}$ & 2.68 & 1.65 & Moderate \\
\hline 4 & I graciously accept the constructive criticism. & 2.69 & 1.62 & Moderate \\
\hline 5 & $\begin{array}{l}\text { I have the ability to find appropriate solutions to the } \\
\text { personal and social problem that I might face. }\end{array}$ & 2.75 & 1.59 & Moderate \\
\hline 6 & I speak fluently, clearly and loud enough. & 2.80 & 1.55 & Moderate \\
\hline \multirow[t]{2}{*}{7} & I can provide attention to all students during training. & 3.01 & 1.67 & Moderate \\
\hline & Overall & 2.70 & .68 & Moderate \\
\hline
\end{tabular}

Table 4 shows that the level of overall perceived personal and social competencies among physical education teachers was moderate $(M=2.70, S D=.68)$. The means of teachers responses to the items of personal and social competencies scale varied between low $(M=2.45$, $S D=1.64)$ and moderate $(M=3.01, S D=1.67)$. The teachers responded most favorably to item 7 "I can provide attention to all students during training" $(M=3.01, S D=1.67)$. The teachers responded least favorably to item 1 "I can use the appropriate reinforcement methods for students' behavior" ( $M=2.45, S D=1.64)$.

\subsubsection{Motivational competencies}

The results suggest that the participants perceived level of motivational competencies was moderate (Table 5) 
Table 5. Descriptive statistics of participants' responses to perceived level of motivational competencies scale. $(\mathrm{N}=127)$

\begin{tabular}{|c|c|c|c|c|}
\hline & Motivational competencies & $\mathbf{M}$ & SD & Level \\
\hline 1 & $\begin{array}{l}\text { I can recognize and honor distinguished students in } \\
\text { front of other students. }\end{array}$ & 2.01 & .99 & Low \\
\hline 2 & $\begin{array}{l}\text { I can express cheerfulness and optimism when the } \\
\text { students achieved the educational goals and } \\
\text { objectives. }\end{array}$ & 2.10 & 1.10 & Low \\
\hline 3 & $\begin{array}{l}\text { I can facilitate competitive educational } \\
\text { environment and I motivate them to achieve the } \\
\text { educational goals and objectives. }\end{array}$ & 2.62 & 1.16 & Moderate \\
\hline 4 & I can encourage the students to do their best. & 2.65 & 1.16 & Moderate \\
\hline 5 & $\begin{array}{l}\text { I can encourage entrepreneurship among the } \\
\text { students and encourage them to help each others. }\end{array}$ & 2.65 & 1.16 & Moderate \\
\hline 6 & $\begin{array}{l}\text { I can respect the feelings of the students and I can } \\
\text { avoid ridicule. }\end{array}$ & 3.10 & 1.18 & Moderate \\
\hline & Overall & 2.52 & .65 & Moderate \\
\hline
\end{tabular}

Table 5 shows that the level of overall perceived motivational competencies among physical education teachers was moderate $(M=2.52, S D=.65)$. The means of teachers responses to the items of motivational competencies scale varied between low $(M=2.01, S D=.99)$ and moderate $(M=3.10, S D=1.18)$. The teachers responded most favorably to item 6 "I can respect the feelings of the students and I can avoid ridicule." $(M=3.10, S D=1.18)$. The teachers responded least favorably to item 1 "I can recognize and honor distinguished students in front of other students." ( $M=2.01, S D=.99)$.

5.2 Second research question: Are there any statistically significant differences $(\alpha<0.05)$ in physical education teachers perceived levels of educational competencies based on their gender and academic qualification.

In order to answer the second research question regarding the variations in participants perceptions of the levels of their educational competencies based on their gender and academic qualification; statistical analysis were performed. The following sections present the findings of the analysis.

5.2.1 Perceived educational competencies and participants' gender

In order to examine the variations in participants' perceptions of the levels of their educational competencies based on their gender, t-tests were conducted (Table 6). 


\section{Macrothink}

Table 6. Descriptive Statistics and results of t-tests for the perceived level of competencies based on the gender

\begin{tabular}{|c|c|c|c|c|c|c|c|}
\hline $\begin{array}{l}\text { The dependant } \\
\text { variable }\end{array}$ & Gender & n & Mean & SD & $\begin{array}{l}\text { Degree } \\
\text { of } \\
\text { freedom }\end{array}$ & $\mathbf{t}$ & Sig \\
\hline \multirow{2}{*}{$\begin{array}{l}\text { Planning } \\
\text { competencies }\end{array}$} & Male & 56 & 2.69 & .67 & \multirow[t]{2}{*}{125} & \multirow[t]{2}{*}{4.28} & \multirow[t]{2}{*}{0.00} \\
\hline & Female & 71 & 2.24 & .52 & & & \\
\hline \multirow{2}{*}{$\begin{array}{l}\text { Implementation } \\
\text { competencies }\end{array}$} & Male & 56 & 3.77 & .58 & \multirow[t]{2}{*}{125} & \multirow[t]{2}{*}{4.10} & \multirow[t]{2}{*}{0.00} \\
\hline & Female & 71 & 3.34 & .57 & & & \\
\hline \multirow{2}{*}{$\begin{array}{l}\text { Personal and social } \\
\text { competencies }\end{array}$} & Male & 56 & 2.89 & .66 & \multirow[t]{2}{*}{125} & \multirow[t]{2}{*}{2.82} & \multirow[t]{2}{*}{0.006} \\
\hline & Female & 71 & 2.56 & .66 & & & \\
\hline \multirow{2}{*}{$\begin{array}{l}\text { Motivational } \\
\text { competencies }\end{array}$} & Male & 56 & 2.63 & .49 & \multirow[t]{2}{*}{125} & \multirow[t]{2}{*}{1.67} & \multirow[t]{2}{*}{0.198} \\
\hline & Female & 71 & 2.44 & .74 & & & \\
\hline \multirow[t]{2}{*}{ Overall } & Male & 56 & 3.01 & .21 & \multirow[t]{2}{*}{125} & \multirow[t]{2}{*}{10.32} & \multirow[t]{2}{*}{0.00} \\
\hline & Female & 71 & 2.65 & .18 & & & \\
\hline
\end{tabular}

Table 6 shows that there were significant differences at $(\alpha<0.05)$ between the means of the physical education teachers' responses to planning competencies $t(125)=4.28, \mathrm{p}<.05$, implementation competencies $t(125)=4.10, \mathrm{p}<.05$, and personal and social competencies $t$ $(125)=2.82, p<.05$ based on their gender. The male teachers had higher levels of their perceived competencies in these areas compared to the female teachers. Furthermore, Table 6 shows that there were no significant differences $t(125)=1.67, \mathrm{p}>.05$ between the means of the physical education teachers' responses to motivational competencies based on their gender.

\subsubsection{Perceived educational competencies and participants' academic qualification}

In order to examine the variations in participants' perceptions of the levels of their educational competencies based on their academic qualification, t-tests were conducted (Table 7). 


\section{Ml Macrothink}

Table 7. Descriptive Statistics and results of t-tests for the perceived level of competencies based on the academic qualification

\begin{tabular}{|c|c|c|c|c|c|c|c|}
\hline $\begin{array}{l}\text { The dependant } \\
\text { variable }\end{array}$ & $\begin{array}{l}\text { Academic } \\
\text { qualification }\end{array}$ & $\mathbf{n}$ & Mean & SD & $\begin{array}{l}\text { Degree } \\
\text { of } \\
\text { freedom }\end{array}$ & $\mathbf{t}$ & Sig \\
\hline \multirow[t]{2}{*}{$\begin{array}{l}\text { Planning } \\
\text { competencies }\end{array}$} & $\begin{array}{l}\text { Undergraduate } \\
\text { degree or below } \\
\text { degree }\end{array}$ & 108 & 2.36 & .58 & \multirow[t]{2}{*}{125} & \multirow[t]{2}{*}{3.65} & \multirow[t]{2}{*}{0.000} \\
\hline & Graduate degree & 19 & 2.90 & .65 & & & \\
\hline \multirow[t]{2}{*}{$\begin{array}{l}\text { Implementation } \\
\text { competencies }\end{array}$} & $\begin{array}{l}\text { Undergraduate } \\
\text { degree or below } \\
\text { degree }\end{array}$ & 108 & 3.48 & .61 & \multirow[t]{2}{*}{125} & \multirow[t]{2}{*}{2.42} & \multirow[t]{2}{*}{0.017} \\
\hline & Graduate degree & 19 & 3.84 & .60 & & & \\
\hline \multirow[t]{2}{*}{$\begin{array}{l}\text { Personal and } \\
\text { social } \\
\text { competencies }\end{array}$} & $\begin{array}{l}\text { Undergraduate } \\
\text { degree or below } \\
\text { degree }\end{array}$ & 108 & 2.67 & .67 & \multirow[t]{2}{*}{125} & \multirow[t]{2}{*}{1.40} & \multirow[t]{2}{*}{0.163} \\
\hline & Graduate degree & 19 & 2.90 & .69 & & & \\
\hline \multirow[t]{2}{*}{$\begin{array}{l}\text { Motivational } \\
\text { competencies }\end{array}$} & $\begin{array}{l}\text { Undergraduate } \\
\text { degree or below } \\
\text { degree }\end{array}$ & 108 & 2.47 & .66 & \multirow[t]{2}{*}{125} & \multirow[t]{2}{*}{2.12} & \multirow[t]{2}{*}{0.036} \\
\hline & Graduate degree & 19 & 2.81 & .48 & & & \\
\hline \multirow[t]{2}{*}{ Overall } & $\begin{array}{l}\text { Undergraduate } \\
\text { degree or below } \\
\text { degree }\end{array}$ & 108 & 2.75 & .22 & \multirow[t]{2}{*}{125} & \multirow[t]{2}{*}{6.59} & \multirow[t]{2}{*}{0.000} \\
\hline & Graduate degree & 19 & 3.12 & .26 & & & \\
\hline
\end{tabular}

Table 7 shows that there were significant differences at $(\alpha<0.05)$ between the means of the physical education teachers' responses to planning competencies $t(125)=3.65, p<0.05$, implementation competencies $t(125)=2.42, p<.05$, and motivational competencies $t(125)$ $=2.12, p<0.05$ based on their academic qualification. The physical education teachers who hold graduate degree had higher levels of their perceived educational competencies in these areas compared to the physical education teachers who hold undergraduate degree or 
academic degree below the bachelor level. Furthermore, Table 7 shows that there were no significant differences $t(125)=1.40, p>.05$ between the means of the physical education teachers' responses to personal and social competencies based on their academic qualification.

\section{Discussion and Conclusion}

The aim of this study was to investigate Jordanian physical education teachers' perceptions of their teaching competencies and to examine potential differences in physical education teachers' perceptions of their teaching competencies based on their gender and academic qualification. The researchers developed a questionnaire instrument that consisted of 27 , five-point Likert-type, items grouped into four dimensions: planning competencies, implementation competencies, personal and social competencies, and motivational competencies. The validity and reliability of the used instrument were verified. The number of the participants in the current study was 127 physical education teachers in the schools in the Southern Governorates of Jordan

In order to answer the first research question regarding the participants' perceptions of the levels of their educational competencies, descriptive statistics were used. The participants' perceptions of the levels of their educational competencies varied between low to high. The findings are similar to some extent to the results of some similar studies. For instance, Hand (2014), Abd-Albaqi et al, (2011), and Selim and Hassan (2011) found that physical education teaching possessed moderate to high level of educational competencies. While, Al-Rawahi and Al-Hanai (2013) found that physical education teaching possessed low to high level of educational competencies.

The participants believed that the highest level in their educational competencies was in the implementation domain. The participants' perceptions of the level of their overall educational implementation competencies was high $(M=3.53, S D=0.62)$. The finding is consistent with the results of some similar studies (Abu-Nimra, 2003; Stojanović \& Zdravković, 2012; Al-Rawahi \& Al-Hanai, 2013; Hand, 2014). However, this finding is inconsistent with the results of other studies. For instance, Abd-Albaqi et al, (2011) found that physical education teachers had a moderate level of implementation competencies.

Some items in the implementation competencies scale scored higher than other ones. A high percentage of participants agreed that they can demonstrate sport skills; recognize individual differences; use sport tools; and present different components of the sport lessons. A moderate percentage of participants agreed that they can build on the students' sports skills, clearly explain the sport skills, and use appropriate educational methods. A possible explanation of physical education teachers' high level of implementation competencies is the high quality education that they have received in their undergraduate study in the university. The university courses, in the physical educational domain, focus on teaching physical education student teachers how to effectively implement educational courses; master sport skills, use sport tools, and analyze and present the educational contents. Another possible explanation is that, teacher training programs usually focus on educational implementation competencies since these competencies reflect and represent accurate teachers' capabilities in 
teaching. A possible explanation of physical education teachers' moderate implementation competencies in some areas is related to teachers' lack of connection and association among the physical education curriculum in consecutive grades, where that make the teachers have moderate knowledge and skills to build on and link students' sports skills and experience. In addition, the teacher training programs might not focus enough on training teachers on how to select and use appropriate educational methods.

The participants believed that the lowest level in their educational competencies was in the planning domain. The participants' perceptions of the level of their overall educational planning competencies was low $(M=2.44, S D=0.62)$. The finding is inconsistent with the results of some similar studies that found that physical education teachers had high level of planning competencies (Abu-Nimra, 2003; Stojanović \& Zdravković, 2012). Some items in the planning competencies scale scored higher than other ones. A moderate percentage of participants agreed that they can match the educational activities to the available facilities, create educational plans, and select appropriate sports tools to achieve the educational objectives. A low percentage of participants agreed that they can employ the educational activities proposed by the ministry of education, choose appropriate educational objectives for each educational stage, set the educational objectives and goals, and identify appropriate educational procedures. A possible explanation of physical education teachers' moderate and low planning competencies is the physical education programs in the university do not focus on these competencies. In addition, the teacher training programs focus on implementation competencies rather than planning competencies. Furthermore, the physical education curriculum in schools might not organize in ways that help teachers to select and use appropriate educational objectives and procedures. The Jordanian ministry of education recommends physical education teachers with educational activities but it seems it does not provide proper training for teachers on how to use them.

The participants' perceptions of the level of their overall personal and social competencies was moderate $(M=2.70, S D=0.68)$. A moderate percentage of participants agreed that they can effectively manage classroom, accept criticism, solve students' problems, and provide attention to students. The finding is inconsistent with the results of some similar studies. For instance, Al-Rawahi and Al-Hanai (2013) found that physical education teachers had low level competencies in solving students' problems and high level competencies in managing the classroom. In the current study, all the items in the personal and social competencies scale scored moderate level except for the item that stated that "I can use the appropriate reinforcement methods for students' behavior." A low percentage of participants agreed that they can provide appropriate reinforcement for students. The finding is consistent with the results of similar studies. For instance, Al-Rawahi and Al-Hanai (2013) found that physical education teachers had low level competencies in reinforcement domain. A possible explanation of physical education teachers' moderate level of classroom management and solving students' problems competencies are the cultural and social changes in the society driven by the technological developments. The teachers have difficulties to face new and unaccepted students' behaviors that emerged due to the cultural and social changes. Furthermore, education programs in the university do not focus on personal and social 
competencies. In addition, teacher training programs do not address such personal and social competencies.

The participants' perceptions of the level of their overall motivational competencies was moderate $(M=2.52, S D=0.65)$. Some items in the motivational competencies scale scored higher than other ones. A moderate percentage of participants agreed that they can facilitate competitive educational environment, encourage the students to do their best, encourage entrepreneurship among the students, and respect the feelings of the students. A low percentage of participants agreed that they can recognize distinguished students and express cheerfulness when the students achieved the educational objectives. The finding is inconsistent with the results of similar studies. For instance, Demir (2015) found that physical education teachers had high level of motivational competencies. A possible explanation of physical education teachers' moderate level of motivational competencies is related to the lack of training for physical education teachers on how to motivate students either in their university education or teacher training programs.

In relation to the answer of the first part of second research question, the findings showed that there were significant differences in the physical education teachers' perceptions of the levels of their educational competencies based on their gender. This was true for all the domains of educational competencies except for the motivational competencies, there were no significant differences in the physical education teachers' perceptions of the level of their motivational competencies based on their gender. The male teachers had a higher levels of their perceived educational competencies compared to the female teachers. The male physical education teachers are more involved than female physical education teachers in the sport domain due to the social and cultural norms of the Jordanian society and the limits on the female teachers to participate in public sport activities, programs, and tournaments. In addition, the available sports facilities in the university are more appropriate for male students rather than for female students (Al-Tawel \& AlJa'afreh, 2017), that make the male physical education teachers more involved in sports domain compared to female students. Therefore, male physical teachers are more active in sport field since they have practical sports experiences, which make them more confident in planning, demonstrating, implementing sports and physical activities and programs. In addition, that makes them more confident in managing physical education classes and dealing with their students. One possible reason for insignificant difference between male and female physical education teachers in the level of their motivational competencies is that motivations skills and knowledge are general competencies rather than being specifically related to physical education. Therefore, male and female physical education teachers developed moderate motivational competencies during their study in the university and teaching practice in the schools.

The finding, regarding the male teachers had higher level of competencies than female teachers, was similar to the finding of Selim and Hassan's (2011) study that found the male teachers outperformed female teachers in some domains of educational competencies. However, the finding was inconsistent with the findings of other research studies which found that there were no significant differences in the physical education teachers' perceptions of the levels of their educational competencies based on their gender (Abu-Nimra, 
2003; Stojanović \& Zdravković, 2012; Al-Rawahi \& Al-Hanai, 2013)

In relation to the answer of the second part of second research question, the findings showed that there were significant differences in the physical education teachers' perceptions of the levels of their educational competencies based on their academic qualification. This was true for all the domains of educational competencies except for personal and social competencies, there were no significant differences in the physical education teachers' perceptions of the level of their personal and social competencies based on their academic qualification. The teachers, who had graduate degree, had a higher levels of their perceived educational competencies compared to the teachers who had undergraduate degree or academic degree below the bachelor level. Physical education teachers who hold graduate degrees would receive more training and education than teachers without graduate degree on the sports subject matters and teaching methods. Therefore, physical education teachers who hold graduate degrees would be more confident in planning and implanting sports and physical activities and programs than teachers without graduate degrees. In addition, the physical education teachers who hold graduate degrees have become more knowledgeable and skillful in motivating students due to the received education and training in their postgraduate study. One possible reason for insignificant difference between physical education teachers who hold graduate degree and who do not hold graduate degree in the level of their personal and social competencies is some personal and social skills and knowledge are gained by experience rather than education. The finding, regarding the teachers who had graduate degree had higher level of competencies than the teachers who had undergraduate degree or academic degree below the bachelor level, was different to the finding of Abu-Nimra's, (2003) study which found that there were no statistically significant differences in the perceptions of teachers and school principals of the level of educational competencies of physical education teachers based on their academic qualification.

\section{Recommendations}

The results recommended that there are needs to provide physical education teachers in the Southern Governorates of Jordan with appropriate teacher training programs. These programs should focus on their planning, social and personal, and motivational competencies. In addition, the physical education programs at the local universities, that provide schools with teachers, should work on enhancing their programs and consider providing students with planning, social and personal, and motivational knowledge and skills.

Teacher training programs should address the variations between the female and male physical education teachers. The focus of these programs should be directed to enhance female physical education teachers' educational competencies. These teachers should be more involved in the physical education field through encouraging them to participate in sports programs and making available sports facilities that are designated for females in the universities and schools.

Teacher training programs should address the variations between the teachers with different academic qualification. More training is needed for teachers who hold undergraduate degree or below the bachelor level degree on specific competencies i.e., implementation, planning, 
and motivational. Finally, there is a need to conduct similar research studies that examined other types of competencies needed for physical education teachers using different research methods and involved different stakeholders e.g., students, supervisors and principles.

\section{References}

Abd-Albaqi, M., Farid, S., Abdul-Reda, H., Laykh., K., \& Mohammed,. S. (2011). Educational competencies for teachers and teachers of physical education in the Middle Euphrates governorates. Journal of Physical Education Sciences, 3(4), 36-48

Abdul-Samie, M., \& Hawala, S. (2005).Teacher's preparation, development and training. Amman: Dar El Fikr

Abu-Jameh, M. (2013). The Role of Educational Supervisors in Improving the Efficiencies of Sport Education Teachers in Gaza Governorates' Public Schools in Light of Total Quality Standards. (Unpublished Master Thesis). Al-Azhar University - Gaza

Abu-Nimra, M. (2003). The basic educational competencies of the primary stage teachers who are required to teach physical education. Najah University Journal of Research (Humanities), 17(2), 501-538

Al-Rawahi, N., \& Al-Hanai, J., (2013) . Instructional competencies of Omani physical education teachers and their relationship with reasons behind career choice. Journal of Educational and Psychological Sciences, 14(1), 514-538.

Al-Tawel,A., \& AlJa'afreh, I. ( 2017). A Study of Female Students Perceptions of the Barriers to Participate in Physical and Sports Activities at Al-Hussein Bin Talal University. Journal of Education and Practice, 8(11), 1-10

Askar, A., (2008). Educational competencies and their role in developing the performance of teachers of the future. University of Kirkuk Journal: Humanitarian Studies, 3(2), 174-195

Badeda,M., \& Shabeba, S. ( 2012). The effect of teaching methods on teaching kinetic skills in the class of physical education and sports: A comparative study, Qasidi University, College of Humanities and Social Sciences, Department of Physical and Mathematical Sciences and Techniques, Algeria.

Bailey, R. (2006). Physical education and sport in schools: A review of benefits and outcomes. Journal of school health, 76(8), 397-401. https://doi.org/10.1111/j.1746-1561.2006.00132.x

Bhargava, A., \& Paty, M. (2010). Quintessential competencies of a teacher: A research review. International Journal on New Trends in Education and Their Impaction. Retrieved May 8, 2017 , from http://www.ijonte.org/FileUpload/ks63207/File/2._anupama_bhargava-minaketan_pathy.pdf

Castelli, D. M., \& Beighle, A. (2007). The physical education teacher as school activity director. Journal of Physical Education, Recreation \& Dance, 78(5), 25-28. https://doi.org/10.1080/07303084.2007.10598020

Chen, W., Hypnar, A. J., Mason, S. A., Zalmout, S., \& Hammond-Benett, A. (2014). Chapter 
9 Students' Daily Physical Activity Behaviors: The Role of Quality Physical Education in a Comprehensive School Physical Activity Program. Journal of Teaching in Physical Education, 33(4), 592-610. https://doi.org/10.1123/jtpe.2014-0060

Chen, W., Zhu, W., Mason, S., Hammond-Bennett, A., \& Colombo-Dougovito, A. (2016). Effectiveness of quality physical education in improving students' manipulative skill competency. Journal of Sport and Health Science, 5(2), 231-238. https://doi.org/10.1016/j.jshs.2015.04.005

Demir, E. (2015). Students' Evaluation of Professional Personality Competencies of Physical Education Teachers Working in High Schools. Online Submission, 5(2), 149-157.

Hadidi, M., \& Dahmach, L. (2013). Training Needs of Female Physical Education Teachers in the Jordanian Upper Basic Schools from Their Point of Views. Najah University Journal of Research (Humanities), 27(3), 667-702

Hand, K. E. (2014). Building Confident Teachers: Preservice Physical Education Teachers' Efficacy Beliefs. Journal of Case Studies in Education, 6.

Hilal, Q.,\& Tawfek, M. (2007). Professional competencies required for supervisors of educational activities in light of contemporary international trends, National Center for Educational Research and Development, Cairo.

Kyrgiridis, P., Derri, V., Emmanouilidou, K., Chlapoutaki, E., \& Kioumourtzoglou, E. (2014). Development of a questionnaire for self-evaluation of teacher effectiveness in physical education (SETEQ-PE). Measurement in Physical Education and Exercise Science, 18(2), 73-90. https://doi.org/10.1080/1091367X.2013.866557

Ololube, N. P. (2005). Benchmarking the motivational competencies of academically qualified teachers and professionally qualified teachers in Nigerian secondary schools. The African Symposium, 5(3), 17-37.

Seferoglu, S. S. (2005, December). A study on teaching competencies of teacher candidates. In Proceedings of International Conference on Education (ICE). National University of Singapore, Singapore.

Selim, F., \& Hassan, Z., (2011).Teaching competencies for teachers and teachers of physical education for the basic stage in the centers of governorates of: Irbil, Sulaymaniyah and Dohuk. Journal of Babylon University, 19(4), 781-796

Siegle, D., Rubenstein, L. D., \& Mitchell, M. S. (2014). Honors students' perceptions of their high school experiences: The influence of teachers on student motivation. Gifted Child Quarterly, 58(1), 35-50. https://doi.org/10.1177/0016986213513496

Stojanović, S., \& Zdravković, D. (2012). The self-assessment of personal competences of physical education teachers. Facta universitatis-series: Physical Education and Sport, 10(2), 141-149.

Tul, M., Leskosek, B., Jurak, G., \& Kovac, M. (2015). Perceived importance of slovenian 


\section{Macrothink}

Journal of Studies in Education

ISSN 2162-6952 2017, Vol. 7, No. 2

physical education teachersprofessional competencies. Hacettepe Üniversitesi Eğitim Fakültesi Dergisi (HU Journal of Education), 30(1), 268-281.

Weinert, F. E. (2001). Concept of competence: a conceptual clarification, in Rychen, D. and Salganik, L. (eds): Defining and Selecting Key Competencies, Seattle. 